\section{Pastoral commons/ICCAs in the northeastern mountains of Andalusia and processes of Heritagization}

\section{PABLO DOMINGUEZ}

https://orcid.org/0000-0002-8890-7509

Centre National de la Recherche Scientifique (GEODE), France ; Universitat Autònoma de Barcelona (LASEG-ICTA), Spain ; AMU-IRD (USAGES-LPED), France.

\section{MONTSERRAT VENTURA I OLLER ${ }^{2}$}

https://orcid.org/0000-0001-8534-4643

Universitat Autònoma de Barcelona (AHCISP), Spain.

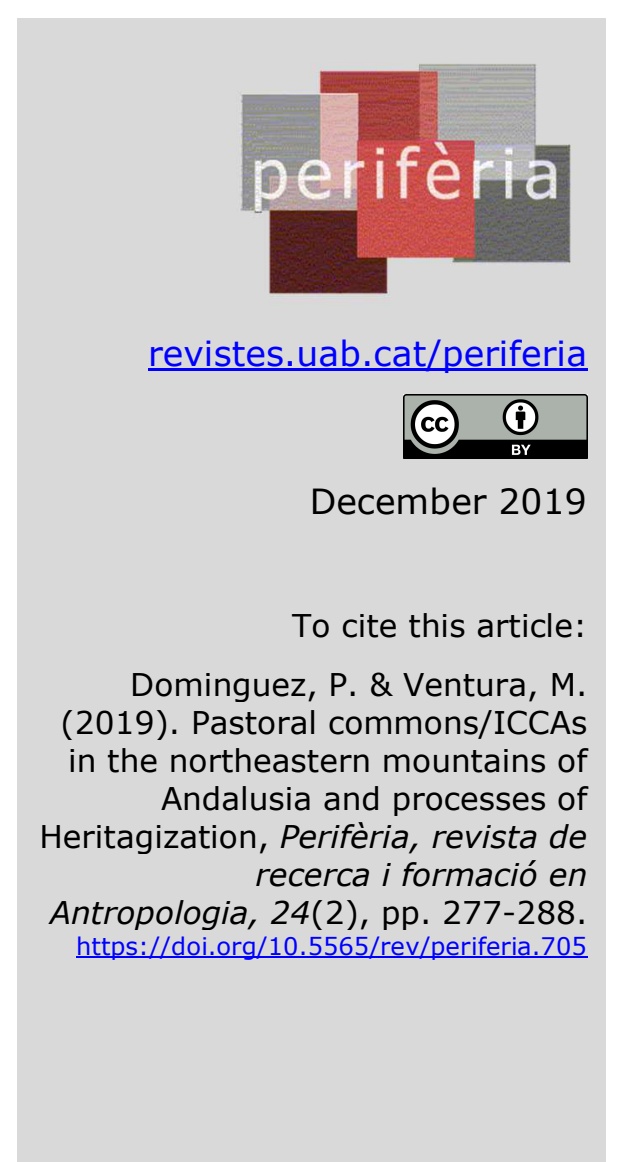

\begin{abstract}
There is a growing scientific awareness that pastoral commons are a positive management regime. Nevertheless, these are undergoing swift degradation processes. Our main Hypothesis is that participative processes of Heritagization have important assets that can contribute to solving key problems faced by Mediterranean pastoral commons. The main Goals of this research project are 1.- to understand drivers motivating differences between commons, 2.- to identify natural and cultural values of these, and 3 . to seek potentials in favour of such systems in terms of heritagization. To achieve this, we explore three neighboring highland pastoral commons of the north-eastern mountains of Andalusia (Spain), through a transdisciplinary and multisectorial methodology.
\end{abstract}

Keywords: Pastoralism; Commons/ICCAs; Mediterranean; Mountains; Political Ecology

Resumen. Comunales pastoriles/ICCAs en las montañas nororientales de Andalucía y procesos de patrimonización (2017-2019)

Existe una creciente conciencia científica de que los comunales pastoriles son un régimen de gestión positivo. Sin embargo, estos están experimentando rápidos procesos de degradación. Nuestra hipótesis principal es que los procesos de Patrimonialización participativa tienen activos importantes que pueden contribuir a resolver problemas clave que enfrentan los comunales pastoriles mediterráneos. Los

\footnotetext{
${ }^{1}$ Contact: Pablo Dominguez - eco.antropologias2@gmail.com

${ }^{2}$ Contact: Montserrat Ventura i Oller - Montserrat.Ventura@uab.cat
} 
objetivos principales de este proyecto de investigación son 1.- comprender vectores que motivan diferencias entre comunales, 2.- identificar valores naturales y culturales de éstos, y 3 . buscar potencialidades a favor de estos sistemas en términos de patrimonialización. Para lograr esto, exploramos tres comunales pastoriles colindantes de las montañas del noreste de Andalucía (España), a través de una metodología transdisciplinaria y multisectorial.

Palabras clave: Pastoralismo; Comunales/ICCAs; Mediterráneo; Montañas; Ecología Política

The project 'Socio-Ecological Heritagization of ICCAs in Spain and Morocco' (CSO2015-72607-EXP), finally mainly evolved towards a study about 'Pastoral commons/ICCAs in the northeastern mountains of Andalusia and processes of Heritagization' that we describe in this research notice. This project has been funded by the Spanish Ministry of Economy and Competitivity, it has been developed from May 2017 to October 2019, it has been based at the Research Group 'Anthropology and History of Construction of Social and Political Identities' (AHCISP), and contributes to the 'Network of Interest on Ethnological Heritage' (XIPE), both of the Department of Social and Cultural Anthropology of the UAB. At the same time it has hosted six PhD students, two Masters students and 13 senior researchers 'belonging to five different institutions beyond the UAB: CSIC (Spain), UVic (Spain), UoC (Spain), IRD (France), ENA (Morocco) and GDF (UK).

\section{State of the art as the base to this research project}

Scientists' interest in the common governance and management of natural resources for local livelihoods and conservation is not new (Bentley, 1949), though only recently the subject has been discussed on solid empirical bases (Ostrom, 1990), possibly also as a reaction to Hardin's provocative but unempirical text of the Tragedy of the commons (Hardin, 1968), which should better be named Tragedy of the open access. In parallel, the last decades have seen the emergence of a specific conception of "commons positively governed by indigenous peoples and local communities". These are territories usually governed by customary institutions and exhibiting very particular cultural traits, under the growingly popular denomination of "Indigenous 
and community conserved areas" (abbreviated as ICCAs). The concept of "ICCA" is today well-established and internationally recognized, especially among environmental conservation and human development actors ${ }^{3}$.

ICCAs

Three basic principles compose the notion of ICCAs: 1.- COMMUNITY: An indigenous people or local community has a strong and profound connection with a territory or area (e.g., because of historical and cultural reasons, or because of survival and dependence for livelihood...); 2.- GOVERNANCE: That people or community is a major player in decision-making and implementation of decisions (governance and management) regarding that territory or area, implying that a community institution exists and has the capacity of developing and enforcing regulations (in many situations other stakeholders are involved, but the people or community have a strong weight de facto on the decision-making); 3.CONSERVATION: The people's or community's governance decisions and management efforts lead to the conservation of nature in the territory, area or habitat, and to the associated conservation of cultural values and community well-being (while the conscious objective of management may be different than conservation per se, and be, for instance, related to material livelihoods, water security, safeguarding of cultural and spiritual places, etc.) (Borrini-Feyerabend, 2010; Kothari, et al., 2012).

In fact, interest in ICCAs has been exponentially growing since its appearance in the early $2000 \mathrm{~s}^{4}$ and they are today considered as a key governance regime for community well-being, local environmental conservation and global sustainability. Among those appreciating and promoting them are the International Union for the Conservation of Nature, the United Nations Development Program and the Convention on Biological Diversity (Kothari et al, 2012; Borrini-Feyerabend, 2004; UNDP, 2014). The key importance of ICCAs for conservation is not only being increasingly recognized by international organizations and scientists, but also by

\footnotetext{
${ }^{3}$ https://www.iccaconsortium.org/index.php/discover/

4 For a brief history of the term see also: https://drive.google.com/open?id=1AoPYMBB0bl8kY8xHa410iatsDx-Rr8W
} 
grassroots organizations ${ }^{5}$. This growingly transversal support to ICCAs is likely to increase given the international policies that point, beyond 'official' protected areas, to "effective area-based conservation measures" (cfr. Aichi Target 11 of the Convention on Biological Diversity). Thus, ICCAs fit this new approach to perfection (CBD, 2010a).

Even if hosting such virtues in terms of biological conservation and ecosystem services, most European ICCA examples and the bio-cultural diversity they sustain are slowly degrading since the implantation of industrial revolution and the rural exodus, phenomena which make their future prospects fragile. Factors such as rural demographic depression, generational shifts, youth migration, new political hierarchies, market integration, cultural globalization, European common agricultural policy (cap) and climate change seem to be at the root of diverse processes of decline. Moreover, most ICCAs are found legally unrecognized and most often outside official protection and even disadvantaged or discriminated by public powers (CBD, 2010b).

Often this is due to a strong communication gap at the commoners-science-policy interface, which encourages the ignorance, undervaluing and/or undermining of ICCAs for what new initiatives are needed (e.g. ICCA Registry: http://www.iccaregistry.org/). In fact, very often protected areas are imposed by governments on inhabitants that use traditional conservation systems with very little or directly without any kind of consent (Stevens, Broome \& Jaeger 2016; Cuffe 2016). In light of this, since the survival of ICCAs entirely depends on local communities' attitudes and actions, the communities themselves need to continue finding incentives (social, cultural, economic, environmental and/or political) in order to carry on governing and managing their ICCAs in the face of mounting adversities and lack of comprehension from much of society. This is why appropriate support, intermediation and dialogue between traditional socio-ecological governance systems and state institutions, the reclamations of scientists and commoners are crucially needed. Their absence is translated by decision-makers into doubts or excuses to avoid action in favor of such traditional heritage values (Aumeeruddy, 2013).

\footnotetext{
5 For instance, iComunales in Spain: http://www.icomunales.org/; European Commons Assembly : https://europeancommonsassembly.eu ; IASC: http://www.iasc-commons.org/.
} 


\section{Heritagization}

Heritage, as defined by Ollagnon (1984), is "the ensemble of material and immaterial elements which contribute to maintain and develop the identity and the autonomy of its holder over time and space by adaptation within an evolutionary environment". From such standpoint, Heritagization can be regarded as a process through which natural and cultural values are acknowledged as heritage at local, national and international levels, through the use of a set of images that contribute to protect it. A heritage element can represent an object with very clear physical borders as much as an abstract notion of identity, whilst at the same time it exemplifies affections and feelings, facilitating social adhesion and unanimity. But its meaning among the heritage users themselves is continuously under redefinition and negotiation and hence, can also drive divergence and disagreement. In this sense, in recent decades there has been a shift in the way we used to classically talk about heritage as we observe today, as almost everything can be turned into heritage. Indeed, since the 1980 s, the concept of heritage has gradually extended its traditional range of meanings, to fields like natural, ethnological, rural or even intangible heritage between other dimensions like 'World heritage' (Roigé \& Frigolé 2010). Interest in heritage has grown, over the last two decades, up to a point that authors like Heinich (2009, p. 15) talk about a heritage inflation. Related to this fact Santamarina et al. (2014) warns about the "heritage bubble", as a result of the heritage explosion together with the neoliberal policies to approach its interpretation.

Heritage growth has been stimulated by the standardization and the extension of its meaning as well as by the globalization of its production (Santamarina et al. 2014). The culmination of this process can be synthesized in the last step given by UNESCO, when including the immaterial in the notion World Heritage (UNESCO 2003). The reasons for this interest in heritage are complex but we could point to a main one. Heritagization can be understood (Roigé \& Frigolé, 2010) as the social process by which a community gives a material or non-material object (e.g. a bio-physical environment, a system of rules that structures social action over such environment, a cosmology that supports it or all three together) the status of heritage. And this concept has proofed to provide sustainable added value to many communities on whose legitimacy lays this heritage potential. As it has been seen in different types of traditional socio-ecological systems (UNESCO, 2014a; UNESCO, 2014b), the 
processes of Heritagization of traditional agro-silvo-pastoralism could effectively contribute to bridging the aforementioned communication gap between public policy and local systems, if communities are included in the processes since the very start and in a participatory way and not elsewise (Michon et al, 2015). In fact, agro-sylvopastoral peoples adhere to initiatives recognizing or adding value to their heritage (conservation sites, animal breeds, objects paradigmatically related to their activity, ceremonies, festivals, know-hows and local practices, etc.).

Nevertheless, nothing is exempt of risk and these processes of Heritagization have also proved to be a failure or counterproductive in many contexts. Senil et al. (2014) highlight the trend towards the folklorisation of the processes of heritage production and the dispossession of the local populations by, for example, top-down approaches to Heritagization instead of bottom-up approaches that come out of the dialogue in equality between local populations and heritage experts. If not, the processes can fall in the reformatting of the local initiatives by foreign actors endowed with economic and political resources that see heritage as an inherited resource of strategic value and which will also depend on the investment to create the demand of a heritage market to turn it into such resource (Greffe, 2003, p. 29). Taddei and Antomarchi (1997) and Comaroff and Comaroff (2009) suggest ideas about an "identity economy", which in fact most often ends up distorting what was initially turned to heritage. At the same time, this process of turning local resources into heritage objects (heritage construction or Heritagization) seeking either to preserve the local identity and/or to promote self-reivindications as well as to support socioeconomic development, or both at the same time, can fit in difficultly if local populations are not placed in the top of the Heritagization demand and command.

Hence, the challenge is to understand how to deal effectively with the concept of Heritagization, avoiding the indiscriminate use of the term but also its automatic rejection, in order to seek always its usefulness in favour of the protagonists of the potentially heritagized object (Santamarina et al. 2014), for which local actors need to play an active and central part. In such context, it is obliged to study the relationship between power and Heritagization as "power is never external to meaning" (Wolf 1990). Thereby the importance of critically analysing the processes and potentials of Heritagization within the framework of a social, economic, environmental and political system and its mutual relationships. 


\section{ICCAs and Heritagization}

Article 31 of the UN Declaration on the Rights of Indigenous Peoples (UN, 2007, pp. 11-12) names the points of convergence and divergence between local and international norms related to the concept of a cultural heritage. These have been mediatized particularly by UNESCO, which developed actions towards the recognition of the "World Heritage" label (Bartolotto, 2011). ICCAs fulfil the definition of heritage in the sense of Ollagnon (2000) exposed above, and although the Heritagization approach in agro-silvo-pastoralist activities is developing quickly and proving effective in many cases (see the paradigmatic case of Cevennes (Brisebarre, 2014) but also the three European projects to which the coordinator of the project Pablo Dominguez is currently directly or indirectly contributing to and that are very Heritagization action-research based (GDF-MAVA ${ }^{6}$, MEDITER $^{7}$ and GEOPARK $^{8}$ ), its explicit application to ICCAs is still nascent.

This is surprising as Heritagization of customary communal governance holds important potential in terms of conservation and sustainable livelihoods and has proven to be recoverable directly by local populations and administrators through heritage participatory approaches (Michon, 2012). Among others, possible paths for this could be the association of ICCAs with the certification of ICCA-linked local products (i.e., natural/biological products, ecologically sustainable, fair trade, high quality or denomination of origin products, etc.), as well as ICCA linked eco/ethnotourism, landscape protection, biodiversity conservation, provision of ecosystem services or risk management, among others (Mahdi \& Dominguez, 2009; PorterBolland, et al., 2012). In addition, key International Organizations ${ }^{9}$ now underline the value of this new emerging paradigm of community governance and management of public and private landscapes through local community governance, towards which we will be shifting in the next decade and in whose frontline the present proposal is situated. In this sense, the lack of research to date on the interface of ICCAs and Heritagization is astonishing and makes this research uniquely original and pertinent,

\footnotetext{
${ }_{7}^{6}$ www.global-diversity.org/conserving-plants-and-cultural-landscapes-in-morocco

7 www.mediter.ird.fr

8 www.paloc.fr/images/2-RECHERCHE/Programmes/GEOPARK PROJECT.pdf

9 United Nation Development Program, International Union for Conservation of Nature, Convention of Biological Diversity.
} 
situating it at a real knowledge frontier and at a pressing social demand for a type of rural traditional productive systems that are currently and for many decades struggling for their continuity.

\section{Objectives}

The project aims at identifying natural and cultural heritage values among three cases in north-eastern Andalusia, the pastoral commons of Castril, Santiago de la Espada and Pontones, which stick out because they are among some of the rare living cases of such systems still present in Andalusia. Moreover, what is even more interesting from a scientific point of view is the fact that it exists a gradient in communalism with Castril having the least vivid institutions of communal governance and Pontones the greatest, with Santiago being an intermediate case. Thus these three cases offer an excellent comparative laboratory for the study of pastoral commons. In such context, the main goals are 1.- to be able to compare the three cases that are very similar ecologically speaking, but different socioanthropologically, in order to understand the drivers of these differences (mostly historical, geographical, economic and cultural), 2.- to identify and record these commons' potential natural and cultural 'heritage' values (past and present), and 3. to systematically examine risks and opportunities of managing such values in the context of on-going and potential future participatory Heritagization procedures.

\section{Preliminary results}

Result. 1. The identification, recording and analysis of natural and cultural 'heritage' values of the three commons/ICCAs of Castril, Santiago de la Espada and Pontones.

Result 2. Holistic understanding of key drivers of the persistence of thriving ICCAs values versus other less present

Result 3. Systematic social and ecological comparison of the three commons/ICCAs.

Result 4. Examination of the risks and opportunities of mobilizing ICCA values in view of potential future and present on-going participatory-collaborative Heritization procedures. 
Result 5. Reflection on possible recommendations about Heritagization potential, focusing on livelihoods opportunities such as certification of ICCAs and legal rights of commoners.

Result 6. Exploration of ways to enrich ICCA studies' holistic methodologies, with particularly strong applicability in Spain and other Mediterranean countries.

Result 7. Drafts for publication in a projected book about Castril, Santiago and Pontones as well as numerous presentations at international conferences.

Result 8. Trained $6 \mathrm{PhD}$ students and 2 Masters students, and raised local management capacities and possibilities for ICCAs' stakeholders.

\section{References}

Aumeeruddy, Y. (2013). Savoirs locaux et biodiversité. En Juhé-Beaulaton, D., Cormier-Salem, M. Ch., de Robert, P. and Roussel, B. (Eds.), Effervescence patrimoniale au Sud (pp. 55-75). Marseille: Ed. IRD. https://doi.org/10.4000/books.irdeditions.8806

Bentley, A.F. (1949). The process of government. Evanston: Principia Press. https://doi.org/10.1177/106591295100400225

Borrini-Feyerabend, G., Kothari, A. and Oviedo, G. (2004). Indigenous and local communities and protected areas: towards equity and enhanced conservation. Gland, Switzerland and Cambridge, UK: IUCN. Available at: https://portals.iucn.org/library/sites/library/files/documents/PAG-011.pdf

Borrini-Feyerabend, G. (coord.) (2010). Bio-cultural diversity conserved by indigenous peoples and local communities- examples and Analysis. Teheran, Iran : ICCA Consortium and Cenesta for GEF SGP, GTZ, IIED and IUCN/CEESP. Available at: http://pubs.iied.org/pdfs/G02786.pdf

Brisebarre, A.M. (2014). Cévennes : des paysages agro-pastoraux inscrits au Patrimoine de I'Humanité (UNESCO), in Vidal-González, P. (Ed.). Landscape anthropology in European protected areas. Valencia: Universidad Católica de Valencia; Sravanger: Reports from the University of Stavanger.

Comaroff, J.L. and Comaroff, J. (2009) Ethnicity, Inc. Chicago: University of Chicago Press. https://doi.org/10.7202/045716ar 
Convention on Biological Diversity (CBD) (2010a). Decision adopted by the Conference of the Parties to the Convention on Biological Diversity at its tenth meeting. Decision X/2: The strategic plan for biodiversity 2011-2020 and the Aichi Biodiversity Targets. 18-29 Oct. Nagoya, Japan: UNEP. Available at: www.cbd.int/doc/decisions/cop-10/cop-10-dec-02-en.pdf

Convention on Biological Diversity (CBD) (2010b). Decision adopted by the Conference of the Parties to the Convention on Biological Diversity at its tenth meeting. Decision X/31: Protected areas. 18-29 Oct. Nagoya, Japan: UNEP. Available at: www.cbd.int/doc/decisions/cop-10/cop-10-dec-31-en.pdf

Greffe, X. (2003). La Valorisation économique du patrimoine. Paris: La Documentation Française.

Hardin, G. (1968). The tragedy of the commons. Science, 162(3859), 1243-8. https://doi.org/10.1126/science.162.3859.1243

Heinich, N. (2009). La fabrique du patrimoine. «De la cathédrale à la petite cuillère». Paris: Éditions de la Maison des sciences de l'homme. https://doi.org/10.4000/books.editionsmsh.2665

Kothari, A., Corrigan, C., Jonas, H., Neumann, A. and Shrumm, H. (eds.) (2012). Recognising and supporting territories and areas conserved by indigenous peoples and local communities: Global overview and national case studies. CBD Technical Series, 64. Montreal, Canada: Secretariat of the Convention on Biological Diversity, ICCA Consortium, Kalpavriksh, and Natural Justice. Available at: www.cbd.int/doc/publications/cbd-ts-64-en.pdf

Loulanski, V. and Loulanski, T. (2014). The heritization of Bulgarian rose. Acta Geographica Slovenica, 54(2). https://doi.org/10.3986/AGS54408

Mahdi, M. and Dominguez. P. (2009). The Moroccan High Atlas agdals: a cultural patrimony in danger. Bulletin Social et Économique du Morocco, 7: 327- 47.

Michon, G. (2012) MED-INN-LOCAL. Innovations au tour de la valorisation des specificités locales dans les arrière-pays Méditerranéens. Etudes Transdiciplinaires Sur l'Avenir de la Mediterranee (Transmed). Agence Nationale de la Recherche. Available at: http://www.agence-nationalerecherche.fr/Projet-ANR-12-TMED-0001

Michon, G., Genin, D., Alifriqui, M., Romagny, B., Boujrouf, S., Sabir, M. and Auclair, L. (2015). Derrière I'huile d'argan, la forêt d'arganiers : écosystème en péril ou terroirs forestiers domestiques? En Berriane, M. and Michon, G. (Eds.), Terroirs 
Méditerranéens: environnement, patrimoine et développement au Maroc (pp. 111-124). Rabat: Ed. Institut de Recherche pour le Développement. https://doi.org/10.4000/books.irdeditions.25919

Ollagnon, H., (1984). Acteurs et patrimoine dans la gestion de la qualité des milieux naturels. Aménagement et nature, 74, 1-4.

Ollagnon, H. (2000). La gestion en patrimoine commun de la qualité de l'eau dans un bassin. En Falque, M. and Massenet, M. (Eds.), Les ressources en eau. Droits de propriété, économie et environnement (pp. 339-341). Paris: Dalloz.

Ostrom, E. (1990). Governing the commons. The evolution of institutions for collective action. Cambridge: Cambridge University Press. https://doi.org/10.1007/978-3-531-90400-9 93

Porter-Bolland, L., Ellis, E.A., Guariguata, M.R., Ruiz-Mallén, I., Negrete-Yankelevich, S. and Reyes-García, V. (2012). Community managed forest and forest protected areas: An assessment of their conservation effectiveness across the tropics. Forest Ecology and Management, 268, 6-17. https://doi.org/10.1016/j.foreco.2011.05.034

Roigé, X. and Frigolé, J. (Eds.) (2011). Constructing cultural and natural heritage. Parks, museums and rural heritage. Barcelona: Documenta Universitaria. https://doi.org/10.1080/13527258.2017.1393447

Santamarina, B., Del Mármol, C. and Beltran, O. (2014). Territorios, memorias e identidades: lógicas y estrategias en la producción patrimonial. Arxius de sociologia, 35(30), 11-16. ISSN 1137-7038

Senil, N., Michon, G., Aderghal, M., Berriane, M., Boujrouf, S., Furt, J-M., Moizo, B., Romagny, B., Sorba, J-M. and Tafani, C. (2014). Le patrimoine au secours des agricultures familiales? Éclairages méditerranéens. Revue Tiers Monde, 220(4), 137-158. https://doi.org/10.3917/rtm.220.0139

Stevens, S., Broome, P. and Jaeger, T. (2016). Recognising and Respecting ICCAs Overlapped by Protected Areas. A Report for the ICCA Consortium. Available at: http://www.iccaconsortium.org/wp-content/uploads/Recognising-andRespecting-ICCAs-Overlapped-by-PAs-Stevens-et-al-2016-r.pdf

UNDP (2016). UNDP support to the implementation of the 2030 agenda for austainable development. UNDP Policy and Programme Brief. New York: UNDP. Available at: www.undp.org/content/dam/undp/library/SDGs/SDG\%20Implementation\%20a 
nd\%20UNDP Policy and Programme Brief.pdf

UNESCO (2014a). Argan, practices and know-how concerning the argan tree. Intangible Cultural Heritage List. UNESCO. Available at: https://ich.unesco.org/en/lists?RL=00955

UNESCO (2014b). Traditional agricultural practice of cultivating the 'vite ad alberello' (head-trained bush vines) of the community of Pantelleria. Intangible Cultural Heritage List. UNESCO. Available at: https://ich.unesco.org/en/RL/traditionalagricultural-practice-of-cultivating-the-vite-ad-alberello-head-trained-bushvines-of-the-community-of-pantelleria-00720

United Nations (2007). United Nations declaration on the rights of indigenous peoples. Geneva-New York : UN. Available at : www.un.org/esa/socdev/unpfii/documents/DRIPS en.pdf

United Nations Development Program / UNDP (2014). German government, GEF, and UNDP partner to create largest global fund for ICCAs. Global Fund Supports Conservation by Indigenous Peoples and Local Communities, Announcements, Oct, 15. UNDP. www.undp.org/content/undp/en/home/presscenter/articles/2014/10/16/global -fund-supports-conservation-by-indigenous-peoples-and-localcommunities.html

Wolf, E.R. (1990). Distinguished Lecture: Facing Power - Old Insights New Questions. American Anthropologist, 92(3), 586-596. https://doi.org/10.1525/aa.1990.92.3.02a00020 